\section{A friend from Wall Street}

\section{Prague}

George Soros, an expatriate Hungarian who made millions on Wall Street, is to put up $\$ 25$ million as seed money for a new English-language university in Prague through his New-York-based 'Open Society Fund'. If delicate negotiations with the interim Czechoslovak government can be completed by the end of this month the university, the first of its kind in Central Europe, may open its doors as early as 1991 .

Soros, who is 59 , has supported cultural and educational causes in Hungary since 1984 by providing nearly $\$ 3$ million a year through the 'Soros Foundation - Hungary', an offshoot of the Open Society Fund. Before the recent ousting of the Communist government, the foundation was known in Budapest as the 'alternative ministry of culture'. The new 'Central European University,' will offer postgraduate courses of up to three years and "support the transition to a market economy", according to physicist Petr Pajas, director of the project in Prague. Although the initial focus will be on the social sciences - a field that was especially deformed by Communist governments according to Pajas - the university may eventually offer courses in natural sciences such as ecology and 'evolution theory' which were also neglected.

The lone remaining obstacle to the project is finding a building in Prague suitable for intensive use as a teaching and research centre. Pajas hopes that the negotiations with the government will proceed smoothly so that the tasks of finding faculty and supplies can begin next month.

The $\$ 25$ million from Soros will be used to attract faculty members, to set up special short courses in the 1990-91 academic year and to lay the groundwork for the full-scale start of the university in the fall of 1991. Fifty students will be taken in at first but Pajas expects numbers to rise to 300. Intensive training in English will be offered at least in the first two years.

Although the building will probably come from the government, Pajas stresses that the goal is "to keep the university as independent of the state as possible". The university will seek private donations for computers, books and other supplies.

An additional site has been chosen at Bratislava, the capital of Slovakia, just east of Vienna. Although the main campus will be in Prague, the full university may eventually feature satellite campuses in Budapest - - where Soros has already set up an international management school with Western professors Vienna and Graz.

Steven Dickman

\section{London}

THE communist legacy of poor training and research management in the environmental sciences compounds Czechslovakia's pollution problems, a Czechoslovak delegation revealed last week. The delegation, led by Zdenek Kukal, research director of the national geological survey, was in London to formulate proposals for support from Britain's 'Know How Fund' for Czechoslovakia. "This is about helping the Czechs to help themselves", says Professor Mike Boulter, from the Polytechnic of East London, who organized the meeting.

Karel Urban, from the Ministry of Culture and Nature Protection, explained that ecology had been viewed as an 'antisocialist' subject. Data on Czechoslovakia's environmental crisis have now been released, and the powerful green lobby is demanding urgent action. But the newly formed environment ministry is financially stretched, lacking even a central headquarters building.

Czechoslovakia has enough graduates in the basic biological sciences, Urban said, but there is a shortage of environmental scientists. Other delegates berated the traditional bias against applied environmental research, and argued that a new system of research management is needed. "We are amateurs in managing research", Kukal said, and suggested that a group of Czechoslovaks should visit Britain to learn from the British system.

Viktor Hoschl, a self-labelled "child of the revolution" and geophysicist with Geoindustria (a state-owned company), said that exchange of information with the West is needed to help Czechoslovakia deal with its accumulating nuclear waste. Under communist control, waste was sent to the Soviet Union.

Peter Aldhous New laws for old

\section{Prague}

Two pieces of legislation of vital interest to the scientific community are among the 63 new laws passed by the Czechoslovak parliament since its reconstruction at the beginning of the year. But there is general anxiety about one of these bills, the law on the universities and higher education, rushed through before the end of the present session.

Essentially, the new law gives more autonomy to university rectors and deans, allows students to participate in university government and opens teaching posts to competition. The fear is that the slapdash way in which the law was drafted may conceal snags that defeat aspirations for the future.

By contrast, the amendment to the law on the Czechoslovak Academy of Sciences, was passed without excitement. The amendments give the elected representatives of academy institutes rights equivalent to those of members of the academy. The new law also abolishes the requirement that academy scientists should compete for their jobs every five years, which had been used for blackmail by the previous regime. However, membership may now be terminated on the grounds of unethical conduct or in cases of members appointed for "non-scientific" reasons.

The legislation also legitimizes the way in which the academy has operated since last December, since when a panel of seven elected scientists has shadowed the decisions of the formal praesidium, exercising a veto on matters with which it disagreed. Now it should be possible for those in charge to turn from criticism of the old order to finding a more logical and less discriminatory way of conducting research.

\title{
Lesotho academic excluded
}

\section{Cape Town}

THE decision to refuse a South African residence permit to Professor Njabulo Ndebele, a citizen of Lesotho who was chosen by the University of the Western Cape (UWC) to be its second vice-rector (see Nature 344, 581; 12 April 1990) was made at cabinet level, according to a statement released by the Minister of Home Affairs and National Education, Gene Louw, after a meeting with UWC rector Jakes Gerwal and vice-rector Jaap Durand on 17 April.

Louw said that Ndebele, an exiled South African, was placed on the government's list of persons to whom visas should not be granted several years ago, and that it was "not customary" for the government to provide reasons why individuals' names appeared on the list.
Louw claimed that government "was accommodating within all reasonable limits" about requests to grant visas to listed people, but "could not be expected to simply submit to all requests from parties who do not possess all the facts". UWC's council has asked for a meeting with President de Klerk to discuss the case.

Although Louw was dealing with this issue in his capacity as Minister for Home Affairs, his action bodes ill for Louw's future relations with the universities as Minister for National Education, his second cabinet portfolio. Louw took over the post last month from Dr Gerrit Viljoen, who is concentrating on his responsibilities as Minister for Constitutional Development and chief negotiator with the African National Congress.

Michael Cherry 